\title{
Effects of cold-storage facility characteristics on the virulence and sporulation of Penicillium expansum and the efficacy of essential oils against blue mold rot of apples
}

\author{
Bochra A. Bahri, ${ }^{1,2 *}$, Ghaya Mechichi', Wafa Rouissi', \\ Imtinen Ben Haj Jilani', Zeineb Ghrabi-Gammar ${ }^{4}$

\begin{abstract}
${ }^{1}$ Laboratory "Bioagresseurs et Protection Intégrée en Agriculture", University of Carthage The National Agronomic Institute of Tunisia, 43 Avenue Charles Nicolle, Tunis 1082, Tunisia ${ }^{2}$ Department of Plant Pathology, 228 Turfgrass Research \& Education Center, University of Georgia, GA 30223, USA ${ }^{3}$ Laboratory of Plant Protection, The National Institute of Agronomic Research of Tunisia, Rue Hedi Karray, 2049 Ariana, Tunisia ${ }^{4}$ Laboratory "Biogeography, Applied Climatology and Dynamics of Erosion", University of Manouba The National Agronomic Institute of Tunisia, 43 Avenue Charles Nicolle, Tunis 1082, Tunisia
\end{abstract}

\begin{abstract}
Blue mold rot, caused by Penicillium expansum, is one of the most economically important post-harvest diseases of apple worldwide. The goals of this study were threefold: to evaluate the diversity of $P$. expansum isolates for mycelial growth, spore production and lesion diameter on apples; to estimate the effects of cold-storage facility conditions on $P$. expansum population structure; and to investigate the efficacy of three essential oils against $P$. expansum. The results showed that storage facilities applying fungicides and storing diverse fruit species selected for $P$. expansum isolates with a larger lesion diameter on apples. In addition, application of fungicides and diversification in stored fruit species significantly select for $P$. expansum isolates with higher levels of mycelial growth and spore production, respectively. Moreover, the diversity of host species of stored fruit accounted for $38 \%$ of the variability observed between storage facilities for the measured fitness parameters in $P$. expansum isolates and had a stronger effect on $P$. expansum population structure than fungicide treatment. Essential oils from Mentha pulegium and Syzygium aromaticum significantly decreased mycelial growth and spore production of $P$. expansum isolates in vitro. Mentha pulegium essential oil also significantly decreased the size of lesions associated with the blue mold rot of apples. Reducing the diversity of stored host species and applying M. pulegium essential oil may be useful in counter-selecting for aggressive $P$. expansum isolates and reducing losses due to blue mold rot during fruit storage.
\end{abstract}

Key words: aggressiveness, clove and white wormwood essential oils, lesion diameter, mint, mycelial growth, post-harvest, spore production

\section{INTRODUCTION}

Blue mold rot, caused by Penicillium expansum, is one of the most important post-harvest diseases of apples worldwide that threatens both the fresh and processing fruit industries. This disease can cause direct losses ranging from 5 to $20 \%$ in developed countries and around 50\% in developing countries (Guerrero et al., 2014). Some strains of $P$. expansum can also produce a mycotoxin, patulin, which affects apple juice quality (Rosenberger, 2014). $P$. expansum penetrates through wounds in the

*Corresponding author. 
pericarp of fruits at harvest, initiating infection in the orchard or during post-harvest handling, resulting in storage rots (Rosenberger, 2014). Fungicides are commonly used to manage blue mold rot and other post-harvest pathogens, such as Botrytis cinerea, which causes gray mold on apples. Fungicides with Benomyl and Thiabendazole (benzimidazole family) were the most commonly-used pesticides in orchards to inhibit pathogen spore germination and spore production. However, because of their extensive use, benzimidazoles became quickly ineffective and cases of resistance to these singlesite fungicides were reported (Morales et al., 2010; Quaglia et al., 2011; Abouraicha et al., 2015; Wallace et al., 2017). Currently, the introduction of demethylation inhibitors, quinone outside inhibitors and succinate dehydrogenase inhibitors, alone or in combination with conventional multi-site effective substance fungicides such as captan and mancozeb, provides the best control of $P$. expansum in orchards. In addition, post-harvest treatments of apples with effective substance fungicides such as fludioxonil (phenylpyrrole family), cyprodinil and pyrimethanil (anilinopyrimidine family) are considered to be effective against blue mold rot (Xiao and Boal, 2009; Errampalli and Crnko, 2010). In Tunisia, blue mold rot is the most prevalent post-harvest fungal disease limiting the storage life of apples. Variability in disease incidence, diversity of phytopathogenic species and pathogen aggressiveness have been reported in storage facilities (Louw and Korsten, 2014; Bahri et al., 2019). Although post-harvest technologies have considerably improved worldwide, making long-term fruit and vegetable storage possible, the storage technologies in Tunisia remain precarious and poorly managed. Cold storage involves maintaining fruits below $4{ }^{\circ} \mathrm{C}$, with a relative humidity of $70 \%$, using a sandwich panel structure as thermal insulation. In Tunisia, some storage facilities store only apples and pears; those with a high-storage capacity are used all year round for a wide range of fruit and vegetable species, including dates, grapes, stone fruits, citrus fruits and potatoes. In the latter type of facility there is a high risk of cross-contamination, especially with polyphagous pathogens (Bahri, unpublished data; Louw and Korsten, 2014). Prior to storage, fruits are sorted by size and visual appearance, and subjected to post-harvest treatments. The postharvest treatments include washing and, in some cases, the application of fungicides. Sanitizing the water system and applying fungicides to fruits prior to storage are critical in reducing the extent of fruit rot and constitute the largest differences among storage facilities. In Tunisia, more than 10 active ingredients are approved for use against scab, powdery mildew and gray mold in apple orchards. The only compound approved for postharvest use in fungicides is thiophanate-methyl (benzimidazole family) on citrus fruits (DGPCQPA, 2017); no fungicide is registered for post-harvest use on apples. Due to international pressure to reduce pesticide application for improving human safety and mitigating environmental risks, the emergence of fungicide resistance cases, and concerns about pesticide residues (Ticha et al., 2008; Morales et al., 2010; Quaglia et al., 2011; Abouraicha et al., 2015; Wallace et al., 2017), there is a need for other alternative methods of disease management. Biological control using microbial antagonists can reduce qualitative and quantitative losses induced by post-harvest diseases (Leverentz et al., 2005; Conway et al. 2007; Janisiewicz et al., 2008; Wallace et al., 2017). More recently, essential oils have emerged as an alternative disease management tool. The allelopathic effects of common thyme (Thymus vulgaris L.), blue gum (Eucalyptus globulus Labill), lemon grass (Cymbopogon citratus Stapf.), clove (Syzygium aromaticum), spearmint (Mentha spicata L.) and lemon bush (Lippia scaberrima Burm. f.) have been reported against post-harvest plant pathogens such as Penicillium sp., Alternaria sp., Botrytis cinerea and Monilinia fructicola on a variety of fresh fruits and vegetables (Kanherkar et al., 2007; Suryawanshi et al., 2007; Antunes and Cavaco, 2010). All of the essential oilstested inhibited pathogen growth in vitro, and when incorporated into the wax coating or used as a dipping solution, they reduced fruit decay incidence, fruit decay losses or lesion diameter in vivo (Klaric et al., 2007; Nguefack et al., 2007; du Plooy et al., 2009; Antunes and Cavaco, 2010; Jhalegar et al., 2015; Abd-ElLatif, 2016). The antifungal activity of essential oils is generally due to their phenolic compounds such as carvacrol and thymol (Dorman and Deans, 2000; Tsao and Zhou, 2000; Plotto et al., 2002; Plaza et al., 2004; Angelini et al., 2006; Guillen et al., 2007; Kim et al., 2008; Numpaque et al., 2011).

The objectives of this research were to (1) evaluate the diversity in virulence of $P$. expansum isolates for mycelial growth and spore production on PDA media and for lesion diameter on apples; (2) study the effects of cold-storage facility conditions, i.e. application of fungicides and the diversification in stored fruit species, on $P$. expansum population 
structure; and (3) investigate the antifungal activity of mint (Mentha pulegium L.), clove (Syzygium aromaticum (L.) Merr. \& L.M. Perry) and white wormwood (Artemesia herba-alba Asso.) essential oils against $P$. expansum in vitro and the activity of mint essential oil on $P$. expansum pathogenicity in vivo.

\section{MATERIALS AND METHODS}

\section{Sampling approach and selection of cold-storage facilities}

In 2015, apple fruits were collected from eight coldstorage facilities at Beni Khaled, the main area for fruit storage in Tunisia. The eight storage facilities were distinguished by two main parameters: the application of fungicides to apples before storage and the diversity in plant species stored during the year. The eight storage facilities were grouped as fungicide-treated and diverse host species (D-T), fungicide-treated and non-diverse host species (ND-T), non-fungicide treated and diverse host species (D-NT) and non-fungicide treated and nondiverse host species (ND-NT) (Tab. 1). Because no active chemical ingredient is approved for use in storage on apple fruits in Tunisia, none of the storage units investigated in this sampling informed us about their precise protective schedules. Therefore, we are lacking information on the exact previous treatments of the research materials besides the application of at least one fungicide treatment for apples from D-T and ND-T storage facilities. Fruits after about 6 to 7 months of storage were sampled from February to April, which represents the usual period of apple storage. In each storage unit, 30 apples were selected from 10 storage boxes (three apples per box) based on box and fruit position in the storage unit and box, respectively, as described by Bahri et al. (2019). All of the apples were of the cultivar Golden Delicious, the most widely distributed variety, both nationally and globally (GIFruits, 2016), and did not present any visible disease symptoms, and were kept separately in bags to avoid cross-contamination prior to fungal isolations.

\section{Isolation of $P$. expansum isolates}

A small piece of apple epicarp $\left(\sim 1 \mathrm{~cm}^{2} ; 0.5 \mathrm{~cm}\right.$ deep) was taken from each apple and placed on PDA medium (Potato Dextrose Agar) in Petri dishes, after surface washes in three different changes of sterilized distilled water. After 7 days of incubation at $24^{\circ} \mathrm{C}$ in the dark, each fungal culture obtained was purified by successive transfers onto fresh PDA plates. Single-spore cultures were prepared from pure colonies growing on PDA using the serial dilution technique (Karaoglanidis et al., 2011). From the 240 apples sampled ( 8 storage units $\times$ 30 apples/storage unit), 73 isolates of $P$. expansum, 63 of Alternaria sp. and one isolate of Fusarium sp. were recovered. In this study, only $P$. expansum cultures were targeted. All of the isolates were maintained as single-spore cultures on PDA plates at $4^{\circ} \mathrm{C}$. The identification of $P$. expansum was based

Table 1. Origin of the 14 P. expansum isolates used for in vitro and in vivo analyses, and the characteristics of the eight cold-storage facilities

\begin{tabular}{|c|c|c|c|c|c|c|}
\hline Storage ID & $\begin{array}{c}\text { Storage } \\
\text { characteristics }\end{array}$ & $\begin{array}{l}\text { Antifungal treatment } \\
\text { before storage }\end{array}$ & $\begin{array}{l}\text { Diversification in } \\
\text { plant species stored }\end{array}$ & $\begin{array}{c}\text { Fruit } \\
\text { species stored }\end{array}$ & $\begin{array}{l}\text { Storage capacity } \\
\quad(\mathrm{T}=\text { tonnes })\end{array}$ & $\begin{array}{l}\text { Isolate } \\
\text { ID }\end{array}$ \\
\hline 1 & D-NT & non-treated & diversified & $\begin{array}{c}\text { apples, pears, citrus, } \\
\text { peaches, apricots, } \\
\text { potatoes... }\end{array}$ & $1500 \mathrm{~T}$ & 12 \\
\hline 2 & D-NT & non-treated & diversified & $\begin{array}{c}\text { apples, pears, citrus, } \\
\text { peaches, apricots, } \\
\text { potatoes... }\end{array}$ & $2000-2500 \mathrm{~T}$ & 2 \\
\hline 5 & D-NT & non-treated & diversified & $\begin{array}{c}\text { apples, pears, peaches, } \\
\text { apricots... }\end{array}$ & $2000 \mathrm{~T}$ & 3 \\
\hline 3 & D-T & treated & diversified & $\begin{array}{c}\text { apples, pears, citrus, } \\
\text { peaches, apricots, } \\
\text { grapes... }\end{array}$ & $1500 \mathrm{~T}$ & $8 ; 9$ \\
\hline 4 & D-T & treated & diversified & all fruits and vegetables & $1000 \mathrm{~T}$ & $11 ; 14$ \\
\hline 7 & ND-T & treated & non-diversified & apples and pears & $300-400 \mathrm{~T}$ & $5 ; 6 ; 10$ \\
\hline 6 & ND-NT & non-treated & non-diversified & apples and pears & $400-500 \mathrm{~T}$ & $1 ; 13$ \\
\hline 8 & ND-NT & non-treated & non-diversified & apples and oranges & $300-400 \mathrm{~T}$ & $4 ; 7$ \\
\hline
\end{tabular}

T, NT, D and ND correspond to treated, non-treated, diversified and non-diversified storage facilities, respectively 
on macroscopic observations of the monosporic colonies on PDA, followed by microscopic observations of spores, and observations of rot symptoms on inoculated apples (see below), in accordance with Vico et al. (2014).

\section{Evaluation of $P$. expansum mycelial growth in vitro}

In vitro mycelial growth was measured as described by Attrassi et al. (2007), for 14 P. expansum isolates, out of the $73 P$. expansum isolates collected, randomly selected from the eight different storage facilities. Plugs (5 mm diameter) were transferred from monosporic cultures on PDA onto fresh PDA plates. The plates were incubated at $24^{\circ} \mathrm{C}$ in the dark and fungal colony diameters were measured at 7 days post-incubation (DPI), with three replications per isolate.

\section{Evaluation of $P$. expansum spore production in vitro}

In vitro spore production was measured for the 14 P. expansum isolates. A plug (5 $\mathrm{mm}$ diameter) was taken from the periphery of a 7-day-old culture of each isolate growing on PDA at $24^{\circ} \mathrm{C}$ and transferred into a sterilized Eppendorf tube containing $1 \mathrm{ml}$ of sterilized distilled water. Each tube was vortexed for $30 \mathrm{~s}$ to homogenize the conidial suspension and the spore concentration of each isolate was determined with a hemocytometer. Three replications were performed for each isolate.

\section{Pathogenicity tests of P. expansum in vivo}

The pathogenicity of 12 out of the 14 P. expansum isolates (isolates 1 to 12) collected from apples in the cold-storage facilities was evaluated by inoculating healthy 'Golden Delicious' apples. Before inoculation, the fruits were surface disinfected with $90 \%$ ethanol, washed with $1 \% \mathrm{NaOCl}$, rinsed with distilled water and air-dried at room temperature. The surface-sterilized apples were wounded once at the equator with a terilized pipette tip by making an injury $\sim 0.5 \mathrm{~cm}$ in diameter. Then, $20 \mu \mathrm{l}$ of a conidial suspension (prepared from a 7-dayold culture) of each isolate, adjusted to $10^{3}$ spores/ $\mathrm{ml}$, was introduced into each wound as described by Karaoglanidis et al. (2011). The inoculation was performed on 4 fruits per isolate, and the controls included fruits treated similarly with sterilized distilled water. The inoculated fruits were stored at $24^{\circ} \mathrm{C}$ and covered with plastic bags to avoid contamination and to maintain high relative humidity. Lesion diameters were measured at 7 DPI. The pathogenicity of the two remaining
P. expansum isolates, of the 14 isolates selected for this study, was confirmed on two "Golden Delicious' apples, as described above, but lesion diameters were not recorded. Fungi were re-isolated from the infected apples in order to confirm Koch's postulates.

\section{Essential oil preparation}

The antifungal activities of essential oils from mint (Mentha pulegium L.), clove (Syzygium aromaticum (L.) Merr. \& L.M. Perry) and white wormwood (Artemesia herba-alba Asso.), three typical plants found in Tunisia (Pottier-Alapetite, 1981; Hajlaoui et al., 2009; Mighri et al., 2009), were tested on $P$. expansum. All of the essential oils were obtained by the water-steam distillation method using stainless steel apparatus (Ben Haj Jilani et al., 2014), and stored at $4^{\circ} \mathrm{C}$ in the dark. The essential oil extracts were prepared from leafy and flowering twig tops of wild $A$. herbaalba collected in Kef (north-western Tunisia) and naturally dried in the laboratory, fresh leaves of M. pulegium, and dried flower buds of S. aromaticum bought from a market in Tunis. Characterization and identification of the components of $A$. herbaalba essential oil from Kef had been previously conducted by GC-MS (Ben Haj Jilani et al., 2014).

\section{Effect of essential oils on P. expansum mycelial growth and spore production in vitro}

The mixing method described by Ozcan and Boyraz (2000) was used to test the antifungal effect of the essential oils on mycelial growth and spore production of the $12 \mathrm{P}$. expansum isolates. Briefly, this method involved placing an agar plug from a 7-day-old pure culture of $P$. expansum at the center of a PDA medium mixed with essential oil at $40 \%$ (160 $\mathrm{ml}$ of essential oil per $400 \mathrm{ml}$ of medium). For control, the isolates were tested on PDA medium with the addition of sterilized distilled water instead of essential oils. Each PDA plate constituted a single replicate and there were three replicates per treatment. The PDA plates were incubated at $24^{\circ} \mathrm{C}$ for 7 days in the dark. The diameters of the mycelial growth and the spore production were then measured as described above.

\section{Effect of essential oils on P. expansum pathogenicity in vivo}

Based on the results of the in vitro experiments, the mint essential oil was selected to further investigate its effect on the infection by 12 P. expansum isolates on 'Golden Delicious' apples. Prior to inoculation, 
the apples were surface disinfected and wounded as described previously. For each treatment, $20 \mu \mathrm{l}$ of mint essential oil was applied to the wounds, and within 15 min., $20 \mu \mathrm{l}$ of $P$. expansum spore suspension $\left(10^{3} \mathrm{spores} / \mathrm{ml}\right)$ was added. The apples were then covered with plastic bags, sprayed with water to ensure high relative humidity and incubated at $24^{\circ} \mathrm{C}$. Lesion diameters were measured at 7 DPI. For controls, apples were inoculated with $P$. expansum after wounds were treated with sterilized distilled water. Each treatment was replicated 3 times.

\section{Data analyses}

The main effects of isolate, storage conditions and essential oil on P. expansum mycelial growth diameter and spore production on PDA, and on $P$. expansum lesion diameter on apples at $24^{\circ} \mathrm{C}$ were tested. All data were subjected to analysis of variance (ANOVA) using the statistical package STATISTICA version 6.0 (StatSoft Inc., 2001). Pairwise mean comparisons were performed using Newman and Keuls test at $p<0.05$. To study $P$. expansum population structure in the different storage facilities, a Principal Coordinate Analysis (PCOA) was performed using STATISTICA version 6.0 based on 10 in vitro and in vivo biological measurements of 12 P. expansum isolates. These measurements included mycelial growth (V1) and spore production (V2) on PDA at $24^{\circ} \mathrm{C}$, lesion diameter on apples at $24^{\circ} \mathrm{C}(\mathrm{V} 3)$, inhibition of mycelial growth and spore production with A. herba-alba (V4, V5), M. pulegium (V6, V7) and S. aromaticum (V8, V9) essential oils, and lesion diameter inhibition with M. pulegium essential oil treatment (V10). In addition, the analyses of variance implemented in STATISTICA version 6.0 were used to investigate the percentage of variability in $P$. expansum fitness traits explained by the diversification in stored fruits, the application of fungicide treatments, and the combination of diversification $\times$ fungicide treatments.

\section{RESULTS}

\section{Effects of storage facility characteristics on $P$. expansum mycelial growth in vitro}

There was a significant effect of $P$. expansum isolates on mycelial growth on PDA at $24^{\circ} \mathrm{C}$ $(p<0.001)$ (Tab. 2A). After 7 days of incubation, isolate 8 from a T-D facility showed the greatest mycelial growth with $2.9 \mathrm{~cm}$ in diameter. In addition, 11 isolates $(7,9,3,10,2,12,14,5,6$, 11 and 4) showed intermediate mycelial growth ranging from 1.9 to $2.5 \mathrm{~cm}$ in diameter. Finally, two isolates (1 and 13) from the same ND-NT storage unit showed the lowest mycelial growth of $1.8 \mathrm{~cm}$ in diameter.

Overall, the isolates from D-T storage facilities exhibited the highest mean mycelial growth with a diameter of $2.3 \mathrm{~cm}$. By contrast, the isolates from D-NT storage units showed the lowest mean mycelial growth $(2 \mathrm{~cm}$ in diameter) (Fig. 1). The effect of the fruit diversification $\times$ treatment interaction on $P$. expansum mycelial growth was significant $(p=0.030)($ Tab. 3A). Fungicide application before apple storage had a significant effect $(p=0.033)$ on the mycelial growth of $P$. expansum isolates only in the diversified storage facilities (Tab. 4A). In fact, the $P$. expansum isolates from D-T storage facilities showed 13\% higher mycelial growth than the isolates from D-NT storage facilities. However, diversification in stored fruit species did not have a significant effect on the mycelial growth of $P$. expansum isolates whether fungicides

Table 2. ANOVA tables for isolate effect on mycelial growth, spore production and lesion diameter

\begin{tabular}{|c|c|c|c|c|c|}
\hline & $\mathrm{DF}$ & SS & MS & $\mathrm{F}$ & $\mathrm{P}$ \\
\hline & A: mycelial growth & & & & \\
\hline Isolate & 13 & 2.5264 & 0.1943 & 4.711 & $0.000290 * * *$ \\
\hline \multirow[t]{2}{*}{ Residuals } & 28 & 1.1550 & 0.0412 & & \\
\hline & B: spore production & & & & \\
\hline Isolate & 13 & 28039.2 & 2156.9 & 1.2336 & 0.308461 \\
\hline \multirow[t]{2}{*}{ Residuals } & 28 & 48955.4 & 1748.4 & & \\
\hline & $\mathrm{C}$ : lesion diameter & & & & \\
\hline Isolate & 11 & 7.7 & 0.7 & 9.8380 & $8.6 \mathrm{e}-08^{* * *}$ \\
\hline Residuals & 35 & 2.5 & 0.1 & & \\
\hline
\end{tabular}

$\mathrm{DF}$ - degrees of freedom; SS - sum of squares; MS - mean squares.

*significant $p<0.05 ; * *$ very significant $p<0.01 ; * * *$ extremely significant $p<0.001$ 


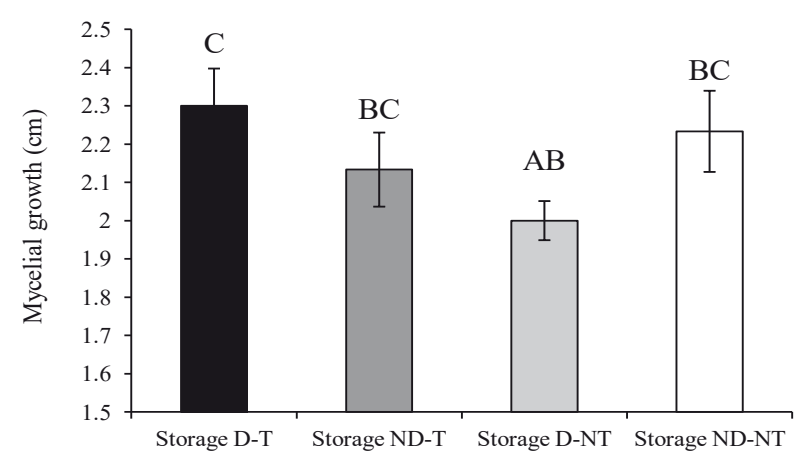

Figure 1. Mycelial growth $(\mathrm{cm})$ of Penicillium expansum isolates after 7 days of incubation on PDA at $24^{\circ} \mathrm{C}$. Isolates were grouped by cold-storage characteristics. T, NT, D and ND correspond to treated, non-treated, diversified and non-diversified storage facilities, respectively. Bars with different letters on top represent statistically significant results $(p<0.05)$ based on Newman-Keuls post hoc analysis.

were applied $(p=0.086)$ or not $(p=0.218)$ (Fig. 1) (Tab. 4A).

\section{Effects of storage facility characteristics on the sporulation of $P$. expansum in vitro}

The variation in spore production among the $P$. expansum isolates observed on PDA at $24^{\circ} \mathrm{C}$ was not statistically significant ( $p=0.308)$ (Tab. 2B). However, two isolates, 11 and 12, from D-T and D-NT storage facilities, respectively, showed the highest spore production $\left(150 \times 10^{6}\right.$ spores/ $\mathrm{ml})$. The majority of the isolates (79\%) exhibited an intermediate spore production between $79 \times 10^{6}$ and $122 \times 10^{6}$ spores $/ \mathrm{ml}$. A single isolate from an ND-T storage unit showed the lowest aggressiveness with a spore production of $45 \times 10^{6}$ spores $/ \mathrm{ml}$.

Moreover, the diversification $\times$ treatment interaction ( $p=0.041)$ had a significant effect on P. expansum spore production (Tab. 3B). Overall, the isolates from D-T storage facilities showed the highest spore production with $120 \times 10^{6}$ spores/ml, whereas those from ND-T storage units displayed the lowest spore production $\left(75 \times 10^{6}\right.$ spores $/ \mathrm{ml}$ ). The storage units that contained diverse fruit species had a significant effect $(p=0.022)$ on isolate spore production in fungicide-treated storage units. The isolates from D-T storage facilities displayed, on average, a 38\% higher spore production than those from ND-T storage facilities. However, the fungicide treatment did not significantly affect the sporulation of $P$. expansum isolates either in the diversified ( $p=0.950)$ or nondiversified ( $p=0.060$ ) storage units. In addition, ND-T storage facilities yielded a significantly lower $P$. expansum spore production than D-NT storage facilities $(p=0.022)$ (Fig. 2) (Tab. 4B).

\section{Effects of storage facility characteristics on $P$. expansum pathogenicity}

A significant difference in mean apple lesion diameter was observed among the $12 P$. expansum isolates tested $(p<0.001)$ (Tab. 2C). Isolate 8 , from a T-D storage facility, showed the largest

Table 3. ANOVA tables for the effects of storage characteristics (fungicide treatment and diversification in stored fruits) on mycelial growth, spore production and lesion diameter

\begin{tabular}{|c|c|c|c|c|c|}
\hline & DF & SS & MS & $\mathrm{F}$ & $\mathrm{P}$ \\
\hline & \multicolumn{5}{|c|}{ A: mycelial growth } \\
\hline Treatment & 1 & 0.1029 & 0.1029 & 1.267 & 0.267397 \\
\hline Diversification & 1 & 0.0114 & 0.0114 & 0.141 & 0.709600 \\
\hline Treatment $\times$ Diversification & 1 & 0.4114 & 0.4114 & 5.068 & $0.030238 *$ \\
\hline \multirow[t]{2}{*}{ Residuals } & 38 & 3.0850 & 0.0812 & & \\
\hline & \multicolumn{5}{|c|}{ B: spore production } \\
\hline Treatment & 1 & 2917.0 & 2917.0 & 4.8554 & 0.194095 \\
\hline Diversification & 1 & 8104.9 & 8104.9 & 3.9986 & $0.033692 *$ \\
\hline Treatment $\times$ Diversification & 1 & 6674.7 & 6674.7 & 3.9986 & $0.041125 *$ \\
\hline \multirow[t]{2}{*}{ Residuals } & 38 & 63430.8 & 1669.2 & & \\
\hline & \multicolumn{5}{|c|}{$\mathrm{C}$ : lesion diameter } \\
\hline Treatment & 1 & 2.008 & 2.0076 & 14.090 & $0.000518 * * *$ \\
\hline Diversification & 1 & 1.736 & 1.7363 & 12.190 & $0.001126 * *$ \\
\hline Treatment $\times$ Diversification & 1 & 0.959 & 0.959 & 11.82 & $0.001295 * *$ \\
\hline Residuals & 38 & 3.0850 & 0.0812 & & \\
\hline
\end{tabular}

$\mathrm{DF}$ - degrees of freedom; SS - sum of squares; MS - mean squares.

*significant $p<0.05 ; * *$ very significant $p<0.01 ; * * *$ extremely significant $p<0.001$ 
Table 4. Newman-Keuls pairwise comparisons between the types of storage facilities for mycelial growth, spore production and lesion diameter

\begin{tabular}{lccc}
\hline & \multicolumn{1}{c}{ D-T } & ND-T & D-NT \\
\hline D-T & A: mycelial growth & & \\
\cline { 2 - 4 } ND-T & 0.218726 & & \\
D-NT & $0.033369^{*}$ & 0.295411 & 0.086368 \\
ND-NT & 0.598893 & 0.431168 & \\
\hline & B: spore production & & \\
D-T & $0.022994 *$ & & \\
ND-T & 0.950614 & & \\
D-NT & 0.562226 & $0.022413 *$ & \\
ND-NT & C: lesion diameter & 0.060968 & \\
\hline & & & \\
D-T & 0.3082548 & 0.9269893 & \\
ND-T & 0.1348074 & $0.0010822^{* *}$ & $0.0079455^{* *}$ \\
D-NT & $0.0000225^{* * *}$ & & \\
ND-NT & & & \\
\hline
\end{tabular}

T, NT, D and ND correspond to treated, non-treated, diversified and non-diversified storage facilities, respectively.

*significant $p<0.05 ; * *$ very significant $p<0.01 ; * * *$ extremely significant $p<0.001$

lesion diameter with an average of $4 \mathrm{~cm}$. Sixtyseven percent $(67 \%)$ of the isolates presented an intermediate level of aggressiveness with lesion diameters ranging from 3.1 to $3.6 \mathrm{~cm}$. Three isolates (isolates 1 and 7 from two NT-ND storage facilities, and also isolate 12 from an NT-D storage unit) showed the smallest lesion diameters $(2.4$ to $2.6 \mathrm{~cm})$. Moreover, diversification of fruit species $(p=0.001)$ and fungicide treatment $(p<0.001)$ had significant effects on the lesion diameter of $P$. expansum isolates (Tab. 3C). With an average lesion diameter

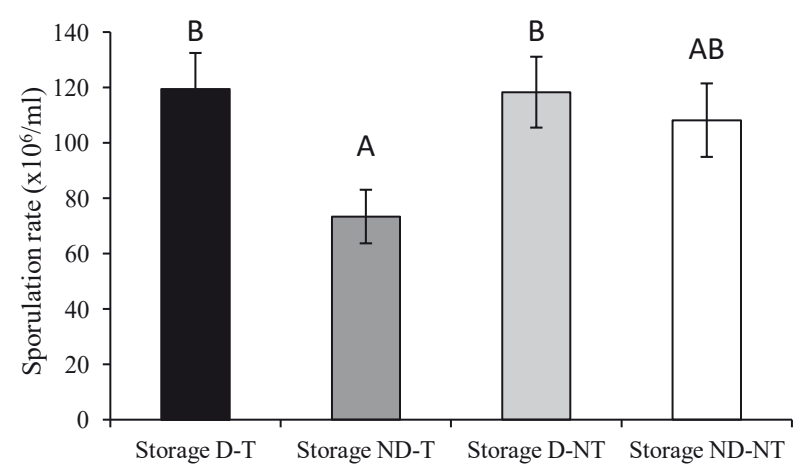

Figure 2. Spore production $(\times 106$ spores $/ \mathrm{ml})$ of Penicillium expansum isolates after 7 days of incubation in PDA at $24^{\circ} \mathrm{C}$. Isolates were grouped by cold-storage characteristics. T, NT, D and ND correspond to treated, non-treated, diversified and non-diversified storage facilities, respectively. Bars with different letters on top represent statistically significant results $(p<0.05)$ based on Newman-Keuls post hoc analysis of $3.3 \mathrm{~cm}$, the isolates from treated storage facilities showed significantly greater lesion diameters than those from untreated storage facilities (mean lesion diameter of $2.9 \mathrm{~cm}$ ). Similarly, the isolates from diversified storage facilities, with a mean lesion diameter of $3.3 \mathrm{~cm}$, produced significantly larger lesions than those from non-diversified storage facilities (with mean lesion diameters of $3 \mathrm{~cm}$ ). Furthermore, on average, the isolates from T-D storage facilities produced significantly larger lesion diameters than those from NT-ND storage facilities $(p<0.001)$. Both the isolates from nontreated apples stored in diversified storage facilities $(p=0.008)$ and the isolates from treated apples stored in non-diversified storage units $(p=0.001)$ had significant effects on lesion diameter (Fig. 3) (Tab. 4C). No correlation was observed between the in vivo lesion diameters and the in vitro mycelial growth of the $P$. expansum isolates, nor between the in vitro mycelial growth of the isolates and the in vitro spore production $\left(R^{2}<5 \%\right.$ ) (data not shown).

\section{Effects of essential oils on P. expansum isolates in vitro and in vivo}

The three essential oils tested showed significant differences at the $5 \%$ threshold $(p<0.001)$, compared to the negative control, in their effects on the mycelial growth $(p<0.004)$ (Fig. 4) (Tab. 5A and Tab. 6A) and spore production $(p<0.001)$ (Fig. 5) of the P. expansum isolates(Tab.5B and Tab. 6B). The clove 


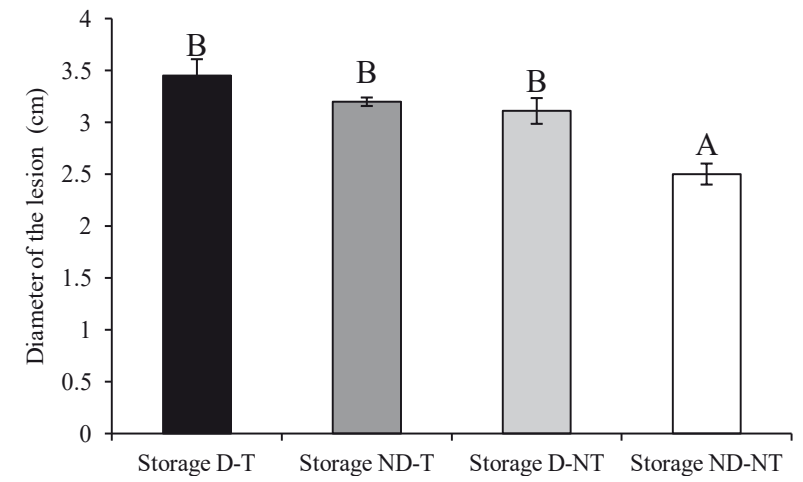

Figure 3. Diameter $(\mathrm{cm})$ of lesions on apples caused by Penicillium expansum isolates after 7 days of incubation at $24^{\circ} \mathrm{C}$. Isolates were grouped by cold-storage characteristics. T, NT, D and ND correspond to treated, non-treated, diversified and non-diversified storage facilities, respectively. Bars with different letters on top represent statistically significant results $(p<0.05)$ based on Newman-Keuls post hoc analysis

(S. aromaticum) essential oil had the most inhibitory effect, which decreased the spore production of the $P$. expansum isolates by up to $97 \%$ and their mycelial growth by $64 \%$ compared to the control. The mint (M. pulegium) essential oil also displayed antifungal activity against the $P$. expansum isolates, especially in respect of spore production (86\% inhibition) and to a lesser extent, mycelial growth (13.6\% inhibition). In addition, the white wormwood essential oil (A. herba-alba) reduced the spore production of the $P$. expansum isolates by $76 \%$. However, we observed a $17 \%$ stimulating effect of white wormwood essential oil on mycelial growth. Moreover, the mint (M. pulegium) essential oil produced a significant $(p<0.001)$ reduction $(25 \%)$ in the lesion diameters of $P$. expansum isolates on apples (Fig. 6) (Tab. 5C). The mean

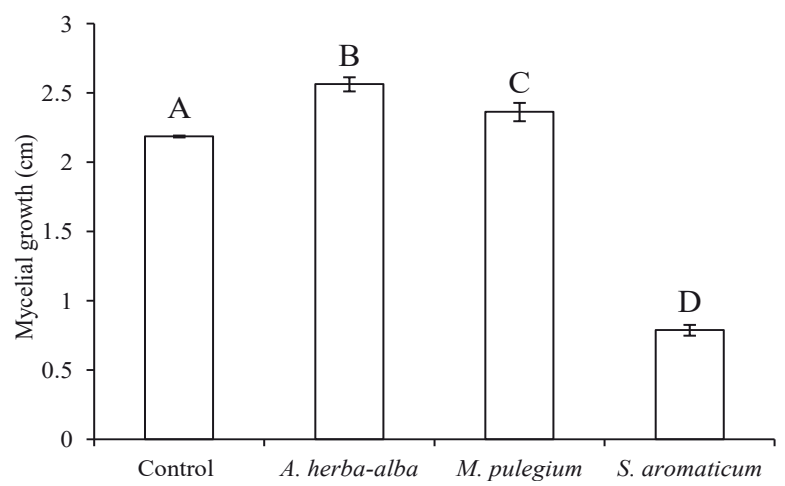

Figure 4. Mycelial growth (cm) of Penicillium expansum isolates after 7 days of incubation in PDA media at $24^{\circ} \mathrm{C}$ in the absence of an essential oil (control) and in the presence of Artemesia herba-alba, Mentha pulegium and Syzygium aromaticum essential oils. Bars with different letters on top represent statistically significant results $(p<0.05)$ based on Newman-Keuls post hoc analysis

lesion diameter was $2.3 \mathrm{~cm}$ when the mint essential oil was applied, compared to $3.1 \mathrm{~cm}$ for the control.

\section{Population structure of $P$. expansum isolates}

The PCoA analysis revealed a structure in the $P$. expansum population sampled from different storage facilities. The first two components of the PCoA explained $47.5 \%$ of the total variation, with the first coordinate explaining $31.4 \%$ and the second coordinate $16.1 \%$ (Fig. 7). Colour-coding of the 12 isolates in the 2-dimensional PCoA plot showed $P$. expansum population structure and an overall clustering corresponding to storage characteristics. Diversified and non-diversified storage facilities, and treated and non-treated storage facilities seem to be distinguishable in the PCoA plot. Two variables, inhibition of $P$. expansum mycelial growth and spore production with mint essential oil

Table 5. ANOVA tables for essential oil (EO) treatment effects on mycelial growth and spore production, and of mint treatment on lesion diameter

\begin{tabular}{|c|c|c|c|c|c|}
\hline & DF & SS & MS & $\mathrm{F}$ & $\mathrm{P}$ \\
\hline & A: mycelial & & & & \\
\hline EO treatment & 3 & 47.28 & 15.759 & 139.8 & $<2 \mathrm{e}-16 * * *$ \\
\hline \multirow[t]{2}{*}{ Residuals } & 104 & 11.72 & 0.113 & & \\
\hline & B: spore pro & & & & \\
\hline EO treatment & 3 & 200305 & 66768 & 91.1 & $<2 \mathrm{e}-16 * * *$ \\
\hline \multirow[t]{2}{*}{ Residuals } & 104 & 76225 & 733 & & \\
\hline & C: lesion dia & & & & \\
\hline Mint treatment & 1 & 9.9494 & 9.9494 & 58.545 & $8.66 \mathrm{e}-11 * * *$ \\
\hline Residuals & 69 & 11.7261 & 0.1699 & & \\
\hline
\end{tabular}

$\mathrm{DF}$ - degrees of freedom; SS - sum of squares; MS - mean squares.

*significant $p<0.05 ; * *$ very significant $p<0.01$; *** extremely significant $p<0.001$ 
Table 6. Newman-Keuls pairwise comparisons between essential oil treatments for mycelial growth and spore production

\begin{tabular}{|c|c|c|c|c|}
\hline & Control & A. herba-alba & M. pulegium & S. aromaticum \\
\hline & A: mycelial growth & & & \\
\hline \multicolumn{5}{|l|}{ Control } \\
\hline A. herba-alba & $0.0002656^{* * *}$ & & & \\
\hline M. pulegium & $0.0037622 * *$ & $0.0038703 * *$ & & \\
\hline \multirow[t]{2}{*}{ S. aromaticum } & $0.0000000 * * *$ & $0.0000000^{* * *}$ & $0.0000000 * * *$ & \\
\hline & B: spore production & & & \\
\hline \multicolumn{5}{|l|}{ Control } \\
\hline A. herba-alba & $0.0000000 * * *$ & & & \\
\hline M. pulegium & $0.0000000 * * *$ & 0.6733869 & & \\
\hline S. aromaticum & $0.0000000 * * *$ & $0.0392729 *$ & 0.3958421 & \\
\hline
\end{tabular}

*significant $p<0.05 ; * *$ very significant $p<0.01 ; * * *$ extremely significant $p<0.001$

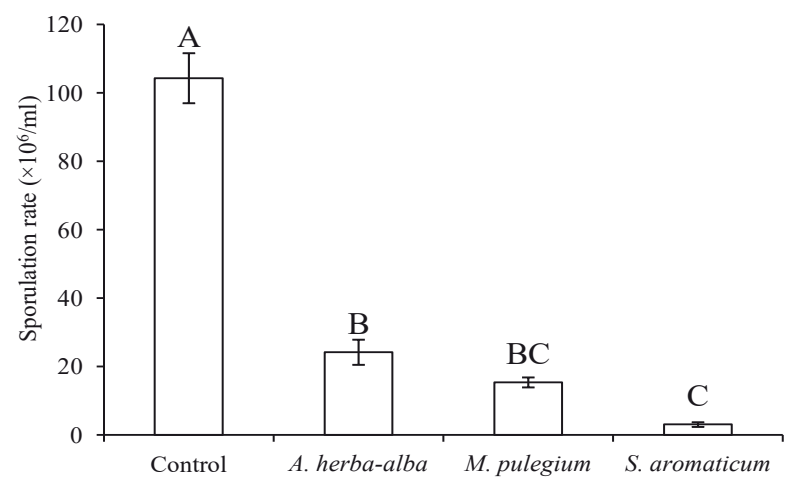

Figure 5. Spore production $\left(\times 10^{6}\right.$ spores/ml $)$ by Penicillium expansum isolates after 7 days of incubation in PDA at $24^{\circ} \mathrm{C}$ in the absence of an essential oil (control) and in the presence of Artemesia herbaalba, Mentha pulegium and Syzygium aromaticum essential oils. Bars with different letters on top represent statistically significant results $(p<0.05)$ based on Newman-Keuls post hoc analysis

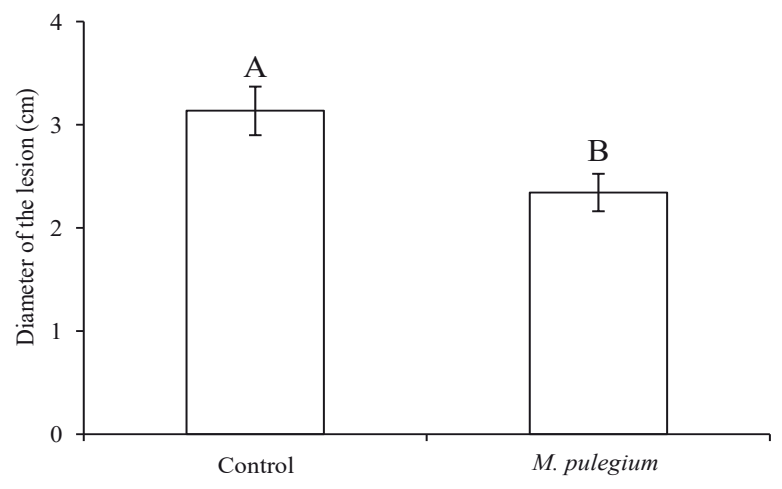

Figure 6. Diameter (cm) of lesions on apples caused by Penicillium expansum isolates after 7 days of incubation at $24^{\circ} \mathrm{C}$ in the absence of an essential oil (control) and in the presence of M. pulegium essential oil. Bars with different letters on top represent statistically significant results $(p<0.05)$ based on Newman-Keuls post hoc analysis

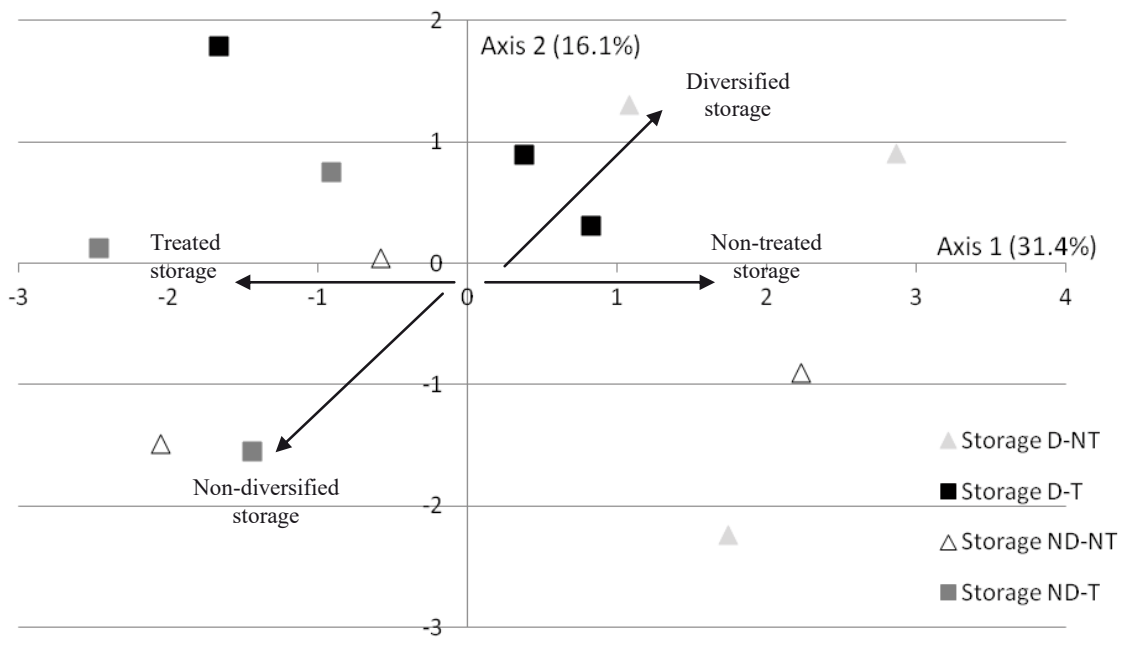

Figure 7. Principal Coordinate Analysis of 12 Penicillium expansum isolates evaluated for 10 in vitro and in vivo biological criteria. T, NT, D and ND correspond to treated, non-treated, diversified and non-diversified types of storage, respectively 
Table 7. Eigen vectors of the first two axes (Axis 1 and Axis 2) of the principal coordinate analysis for the 10 variables assessed in vitro and in vivo on 12 P. expansum isolates, and their contribution to the percentage of variance

\begin{tabular}{lcc}
\hline & Axis 1 $(31.4 \%)$ & Axis 2 $(16.1 \%)$ \\
\hline V1 & -0.63 & 0.26 \\
V2 & 0.56 & 0.02 \\
V3 & -0.33 & 0.76 \\
V4 & -0.69 & 0.23 \\
V5 & -0.59 & -0.43 \\
V6 & -0.43 & -0.74 \\
V7 & -0.75 & 0.04 \\
V8 & -0.62 & 0.09 \\
V9 & -0.32 & -0.40 \\
V10 & 0.51 & -0.10 \\
\hline
\end{tabular}

$\mathrm{V} 1$ to V10 correspond to 10 in vitro and in vivo biological measurements: mycelial growth (V1) and spore production (V2) on PDA media at $24^{\circ} \mathrm{C}$, lesion diameter on apples at $24^{\circ} \mathrm{C}(\mathrm{V} 3)$, mycelial growth and spore production inhibitions with A. herba-alba (V4, V5), M. pulegium (V6, V7) and $S$. aromaticum (V8, V9) essential oils treatments, and lesion diameter inhibition with $M$. pulegium essential oil treatment (V10).

(V6 and V7), contributed the most to the variability observed among the isolates. The inhibition of $P$. expansum mycelial growth with mint essential oil mainly differentiated between diversified and non-diversified storage facilities, while the inhibition of $P$. expansum spore production with mint essential oil mainly differentiated between treated and non-treated storage facilities (Tab. 7). In addition, the analyses of variance indicated that
$38 \%$ of the fitness trait variation in $P$. expansum isolates was due to the differences in diversification between the storage facilities. However, when tested across the treated and non-treated storage facilities, only $4 \%$ of the variation was due to the differences between storage facilities, while $96 \%$ was due to the differences within storage facilities. The combination of diversification $\times$ treatment in the storage facilities explained $30 \%$ of the fitness trait variation in P. expansum isolates (Tab. 8).

\section{DISCUSSION}

Penicillium expansum is the most prevalent postharvest pathogen on apples in Tunisia. It is a widely spread pathogen within storage environments and, over time, its populations could change to maximize survival capabilities that may vary from one storage facility to another. In this study, we tested the effects of the application of fungicides and fruit species diversity on $P$. expansum aggressiveness. Antifungal activities of essential oils from plants found in Tunisia were also assessed on $P$. expansum in order to develop an effective control alternative to fungicides.

\section{P. expansum fitness variability}

Significant differences were observed among the $P$. expansum isolates for mycelial growth on PDA medium and pathogenicity on apples at $24^{\circ} \mathrm{C}$. The differences among the isolates for the measured parameters confirmed the previous report of variability among post-harvest pathogens, including $P$. expansum, isolated from stored

Table 8. Analyses of variance indicating the percentages of variance in Penicillium expansum fitness traits explained by the diversity in stored fruit species, fungicide treatment, and diversification $\times$ treatment interaction in the storage facilities

\begin{tabular}{|c|c|c|c|c|c|}
\hline Source & $\mathrm{DF}$ & SS & MS & Est. Var. & $\%$ \\
\hline & \multicolumn{5}{|c|}{ A: diversity in stored fruit species } \\
\hline Between D and ND storage types & 1 & 3695.156 & 3695.156 & 484.958 & $38 \%$ \\
\hline Within storage types & 10 & 7854.079 & 785.408 & 785.408 & $62 \%$ \\
\hline \multirow[t]{2}{*}{ Total } & 11 & 11549.234 & & 1270.366 & $100 \%$ \\
\hline & \multicolumn{5}{|c|}{ B: fungicide treatment } \\
\hline Between T and NT storage types & 1 & 1261.238 & 1261.238 & 38.740 & $4 \%$ \\
\hline Within storage types & 10 & 10287.996 & 1028.800 & 1028.800 & $96 \%$ \\
\hline \multirow[t]{2}{*}{ Total } & 11 & 11549.234 & & 1067.539 & $100 \%$ \\
\hline & \multicolumn{5}{|c|}{$\mathrm{C}:$ diversification $\times$ treatment interaction } \\
\hline Between ND-T, ND-NT, D-NT and D-T storage types & 3 & 5346.166 & 1782.055 & 335.557 & $30 \%$ \\
\hline Within storage types & 8 & 6203.069 & 775.384 & 775.384 & $70 \%$ \\
\hline Total & 11 & 11549.234 & & 1110.941 & $100 \%$ \\
\hline
\end{tabular}

DF - degrees of freedom; SS - sum of squares; MS - mean squares. T, NT, D and ND correspond to treated, non-treated, diversified and non-diversified storage types, respectively 
apples in Tunisia (Bahri et al., 2019). Similarly, differences were also observed among nine $P$. expansum isolates from 5 storage facilities for their mycelial growth on different media and the diameter of lesions they caused on apples in Serbia (Vico et al., 2014). The differences in pathogenicity between $P$. expansum isolates could highlight their differences in the level of polygalacturonase produced during infection; this enzyme was shown to play a key role in $P$. expansum virulence and tissue maceration (Jurick et al., 2010). In addition, the majority of the isolates in this study showed intermediate behaviour for the different in vitro and in vivo parameters measured at $24^{\circ} \mathrm{C}$, as did those in a previous study (Bahri et al., 2019). This latest study suggested a trade-off between aggressiveness during the infectious phase at $24^{\circ} \mathrm{C}$ (field conditions) and survival in the cold-storage conditions at $4^{\circ} \mathrm{C}$ to explain the maintenance of postharvest pathogen aggressiveness at an intermediate level. Similarly, a trade-off between aggressiveness during growing and over-summering periods and over several seasons explained the maintenance of polymorphism in several pathogen populations (Flier et al., 1998; Koella and Agnew, 1999; Ebert and Bull, 2003).

The ANOVA results and the PCoA analysis indicated a population structure of $P$. expansum in apple storage facilities in Tunisia. The diversity of host species and fungicide application contributed to $P$. expansum variability in aggressiveness parameters such as spore production, lesion diameter and mycelial growth of the isolates. $P$. expansum isolates from T-D storage facilities produced lesion sizes significantly larger than those produced by the isolates from NT-ND storage facilities. However, the isolates from T-D storage facilities exhibited higher, but not significantly different, mycelial growth and spore production than the isolates from NT-ND storage facilities. Thus, fungicide applications combined with the diversification of host species in storage facilities select for $P$. expansum isolates with higher aggressiveness. A similar adaptation was observed in field trials on Zymoseptoria tritici, where isolates from sprayed plots caused a significantly higher percentage of leaf area covered with lesions on susceptible wheat cultivars than isolates from unsprayed plots in both years of the experiment (Cowger and Mundt, 2002). The authors suggested that fungicide treatment could exert similar selective pressures to quantitative host resistance on fungal populations. However, the selection for higher fitness in storage conditions might be different from field selection pressure on $P$. expansum populations. In fact, $P$. expansum populations in the field are also exposed to a strong fungicide selection pressure due to the high number of fungicide treatments targeting apple scab caused by Venturia inaequalis, but also largely effective against blue mold (MacHardy, 1996; Köller and Wilcox, 2001). Several studies have suggested that the extensive use of fungicides could lead to a reduced sensitivity ( $\mathrm{Li}$ and Xiao, 2008; Karaoglanidis et al., 2011) and an increased mycotoxin production (Markoglou et al., 2008) by some pathogenic fungi. Karaoglanidis et al. (2011) showed that $P$. expansum isolates exhibiting reduced sensitivity to DMI and/or dicarboximide and phenylpyrrole fungicides had a significantly lower mycelial growth on PDA media and were significantly less aggressive, with smaller lesion diameters on apples. Thus, sensitive strains, corresponding to the most frequent isolates sampled from fields with no fungicide spray applications, are suggested to have higher fitness than resistant isolates selected under fungicide selection pressure (Karaoglanidis et al., 2011). Similarly, fitness penalties associated with fungicide resistance in laboratory-induced mutants of $P$. expansum have been observed ( $\mathrm{Li}$ and Xiao, 2008). Other studies have also shown reduced competitivity of resistant strains compared to sensitive strains in Penicillium digitatum (Kinay et al. 2007), Botritys cinerea (Ziogas et al., 2005) and Aspergillus parasiticus (Markoglou et al., 2008). In addition, the isolates from T-D storage facilities displayed a significantly higher mycelial growth than those from NT-D storage facilities. Fungicide treatments in storage facilities are important in the selection of isolates with high mycelial growth when diverse host species are stored. Furthermore, the isolates from T-D storage facilities showed a significantly higher spore production than the isolates from T-ND storage facilities. Diversity of fruits in storage facilities is important in the selection of isolates with high spore production when fungicides are applied. Although the statistical analyses in this study showed significant effects of diversification in stored host species and application of fungicides on $P$. expansum virulence and sporulation, assessments of a larger isolate collection are necessary to confirm our findings.

Diversification in stored host species and the application of fungicides accounted for, respectively, $38 \%$ and $4 \%$ of the variability observed among the storage facilities for the measured parameters 
in $P$. expansum isolates. Thus, fruit diversity has a stronger effect in $P$. expansum population structure than fungicide treatment in storage facilities. In addition, the effect of the combination of diversification $\times$ fungicide treatment was not additive on the fitness trait variations in $P$. expansum isolates, since it explained $30 \%$ of the variability observed. Moreover, the results suggested that diversification of host species in the cold-storage facilities played a more important role than fungicide application in the selection for aggressive $P$. expansum isolates, especially in terms of the spore production parameter. In fact, the isolates from T-ND storage facilities showed a significantly lower spore production than the isolates from NT-D storage facilities. A reduction in the diversity of stored host species may be employed to counter-select for aggressive isolates, to avoid significant losses during fruit storage. However, the question remaining to be answered is: What leads to high pathogen virulence in diversified fruit storage? Firstly, the increase in pathogen virulence in diversified fruit storage facilities might be due to large pathogen population sizes leading to competitive pathogen behaviours for survival (Ebert and Mangin, 1997). Secondly, many volatile compounds released by diverse fruits during their ripening process are known for their antifungal activities at sufficient concentrations (Vaughn et al., 1993). Such natural volatiles from other stored fruits might likely select for more virulent $P$. expansum isolates. Chemicals and volatiles at low doses could also lead to hormetic stimulation of fungi (Pradhan et al., 2017). Finally, ethylene is known to increase plant susceptibility and act as a factor of virulence for bacterial and fungal pathogens (Broekaert et al., 2006). Increased ethylene content in diversified fruit storage might trigger selection for greater aggressiveness in pathogens.

\section{Essential oil effects on P. expansum}

The essential oils of mint (M. pulegium) and clove (S. aromaticum) had significant antifungal effects, decreasing the average spore production and mycelial growth of $P$. expansum isolates by $91 \%$ and $28 \%$, respectively. The in vitro results produced by the mint essential oil were consistent with the in vivo tests on apples, illustrating the potential of this essential oil as a biological alternative for blue mold rot management. The antifungal activities of the mint and clove essential oils are in line with previous research carried out on postharvest pathogens such as Alternaria alternata,
Fusarium proliferatum, Lasiodiplodia theobromae, Colletotrichum musae, Aspergillus flavus and P. expansum (Montes-Belmont and Carvajal, 1998; Ranasinghe et al., 2002; Kanherkar et al., 2007; Suryawanshi et al., 2007; Antunes and Cavaco, 2010; Hmiri et al., 2011). In general, the antifungal activities of $M$. pulegium and $S$. aromaticum essential oils are attributed to pulegone and eugenol, respectively (Kong et al., 2004; Chami et al., 2005). $S$. aromaticum essential oils from Tunisia show a high eugenol content ranging from 75.4\% (AguilarGonzalez et al. 2015) to $85.3 \%$ (Pinto et al. 2009). Studies in Morroco and Tunisia have found that the essence of M. pulegium is dominated by pulegone, with concentrations ranging from $44.27 \%$ to $85.4 \%$ (Snoussi et al., 2008; Hajlaoui et al., 2009; Hmiri et al., 2011).

In our study, the $A$. herba-alba essential oil showed, depending on the isolate and the fitness parameter measured, both stimulating and inhibiting effects on $P$. expansum isolates. This essential oil reduced the spore production of $P$. expansum isolates by about $76 \%$. In fact, previous studies had reported antifungal activity of $A$. herba-alba against Fusarium oxysporum (Kolai et al., 2012), Penicilium citrinum, Mucor rouxii (Saleh et al., 2006) and Ephestia kuehniella (Delimi et al., 2013). The culture diameter measurements revealed a stimulating effect of $A$. herba-alba essential oil on $P$. expansum isolates. This effect reduces the chance of using this essential oil against decay agents in storage despite its effect on $P$. expansum spore production. Similar stimulating effects of this volatile essential oil have also been reported on two out of six phytopathogenic strains of Fusarium sp., where the average spore production increased by $186 \%$ compared to the untreated controls (Bahri, unpublished data). Depending on the pathogenic species/isolate used, similar inhibiting and stimulating effects of essential oils from the families Rutaceae and Myrtaceae (Doumbouya et al. 2012; Hamdani et al. 2015), and of hydrosols from different herbs of the families Lamiaceae and Apiaceae (Sagdic and Ozcan, 2003; Boyraz and Ozcan, 2005; Wójcik-Stopczyńska et al., 2012) have been reported. In addition, $A$. herba-alba essential oils from several regions have been characterized, revealing a high level of polymorphism and leading to the characterization of several chemotypes (Haouari and Ferchichi, 2009; Bezza et al., 2010; Ben Haj Jilani et al., 2014). The genus Artemisia is rich in secondary metabolites (flavonoids, essential oils, sterols, acetylenes, etc.), and 32 compounds 
have been identified, representing $92.01 \%$ of the total chemical composition of the $A$. herba-alba essential oil collected in the Kef region in December 2013 (Ben Haj Jilani et al., 2014). The major compounds were chrysanthenone (22.48\%), camphor (13.66\%), and $\beta$-thujone (10.38\%). A. herba-alba essential oils from Spain, Morocco and Algeria also contain a high amount of chrysanthenone (Vernin et al., 1995; Salido et al., 2004), which shows antimicrobial properties (Griffin et al. 1998). Chrysanthenone and camphor have been reported in other essential oils as potential antimicrobial components (Zuzarte et al., 2009; Besbes et al., 2012; Pirbalouti et al., 2013; Mahilrajan et al., 2014). On the other hand, stimulation effects of terpenoid compounds on fungi are unusual. Enhanced growth and fitness parameters of fungi had been observed in previous studies due to the action of components such as limonene, $\beta$-pinene, $\alpha$-pinene, $p$-cymene and myrcene (Bridges, 1987; Filtenborg et al., 1996; Pontin et al. ,2015). Out of these components, $\alpha$-pinene had been detected in A. herba-alba essential oils from Kef, with a concentration of $2.87 \%$ (Ben Haj Jilani et al., 2014).

In this study, mycelial growth was not correlated with spore production of $P$. expansum isolates. In addition, varied patterns between these two fitness traits were observed under different environmental conditions. In fact, all the essential oils in our study inhibited $P$. expansum spore production, whereas both stimulation and inhibition effects were observed for $P$. expansum mycelial growth depending on the essential oil tested. Environmentdependent correlations among components of life-history traits had been suggested in previous studies, showing that the variation for those traits can change under some unfavourable environmental conditions. Positive correlations among fitness traits may be apparent in environmental novelty (Service and Rose 1985) or when resources are abundant (Reznick et al., 2000; Tessier and Woodruff, 2002), while correlations among life-history traits tend to be negative in a resource-poor environment or an environment with increasingly stressful conditions (Hoffmann and Parsons, 1991). Here, the presence of essential oils could be considered as an unfavourable environmental condition for $P$. expansum. Some studies have investigated functional interactions among components of life-history traits to understand the physiological mechanisms of trade-offs and suggested that under scarcity conditions, the resources acquired by the fungus are differentially allocated and trade- offs between fitness parameters can occur (Van Noordwijk and Dejong, 1986; Zera and Harshman, 2001). Spore production may be a crucial $P$. expansum life-history trait under unfavourable conditions, probably to ensure the spread of the species; it was not significantly different among the $P$. expansum isolates and was consistent in all the environments (antifungal essential oils) tested in vitro.

\section{CONCLUSIONS}

Fungicide treatments and/or diversification in host species play an important role in $P$. expansum population in cold-storage facilities by selecting for aggressive isolates with high spore production, mycelial growth and lesion size. Reduction in the diversity of stored fruit species in coldstorage facilities may contribute to reduced losses due to $P$. expansum. In addition, M. pulegium and $S$. aromaticum essential oils significantly decreased mycelial growth and spore production of $P$. expansum isolates in vitro. The M. pulegium essential oil also significantly decreased the size of $P$. expansum lesions on apples and thus may reduce the risk of blue mold rot during storage. Complementary experimental studies encompassing environmental conditions in coldstorage facilities are needed to provide effective recommendations for blue mold rot control. Further testing at temperatures comparable to those applied in the cold-storage facilities (at $4^{\circ} \mathrm{C}$ ) could provide a more accurate picture of the outlook for postharvest disease control based on essential oils and thus highlight their potential to mitigate losses due to post-harvest rots.

\section{ACKNOWLEDGEMENT}

The authors are grateful to Dr. Thomas H. Pendergast at the University of Georgia (Department of Plant Biology) for reviewing the manuscript.

\section{FUNDING}

This project was funded by the Research Laboratory LR14AGR02 "Bioagresseurs et Protection Intégrée en Agriculture"

\section{AUTHOR CONTRIBUTIONS}

B.A.B, G.M. and W.R. - wrote the paper; B.A.B. - developed the concept, designed the experiment and performed data analyses; G.M. and W.R. 
- completed the experiment; G.M., B.H.J.I. and G.G.Z. - obtained essential oil preparations.

\section{CONFLICT OF INTEREST}

The authors declare no conflict of interest.

\section{REFERENCES}

ABD-El-Latif F.M., 2016. Post-harvest application of some essential oils for controlling gray and blue moulds of apple fruits. Plant Pathol. J. 15, 5-10.

Abouraicha E., Elaloui-Talibi Z., El Boutachfaiti R., Petit E., Courtois B., Courtois J., et Al., 2015. Induction of natural defense and protection against Penicillium expansum and Botrytis cinerea in apple fruit in response to bioelicitors isolated from green algae. Sci Hortic. Amsterdam 181, 121-128.

Aguilar-Gonzalez A.E., Palou E., Lopez-Malo A., 2015. Antifungal activity of essential oils of clove (Syzygium aromaticum) and/or mustard (Brassica nigra) in vapor phase against gray mold (Botrytis cinerea) in strawberries. Innov. Food Sci. Emerg. 32, 181-185.

Angelini P., Pagiotti R., Menghini A., Vianello B., 2006. Antimicrobial activities of various essential oils against foodborne pathogenic or spoilage moulds. Ann. Microbiol. 56, 65-69.

Antunes M.D.C., Cavaco A.M., 2010. The use of essential oils for post-harvest decay control. A review. Flavour Frag. J. 25, 351-366.

Attrassi K., Benkirane R., Attrassi B., Douira A., 2007. Effect of the association of certain fungicides with calcium chloride on the development of several fungi responsible for apple rot in conservation. Phytoprotection 88, 17-26.

Bahri B.A., Belaid Y., Mechichi G., Rouissi W., 2019. Diversity of fungi associated with apples in cold storage facilities in Tunisia. J. Am. Pomol. Soc. 73, 62-75.

Ben Haj Jilani I., Chebil S., Khiari R., Melki I., LimamBen SaAd S., Daoud-Bouattour A., et al., 2014. Allelopathic potential of some essential oils vis-à-vis three noxious weed species invading cereals. Int. J. Agron. Agric. Res. 4, 77-97.

Besbes M., Omri A., Cheraif I., DaAmi M., Ben Jannet H., Mastouri M., et AL., 2012. Chemical composition and antimicrobial activity of essential oils from Scabiosa arenaria Forssk. growing wild in Tunisia. Chem. Biodivers. 9, 829-839.

Bezza L., Mannarino A., Fattarsi K., Mikail C., Abou L., Hadji-Minaglou F., et Al., 2010. Chemical composition of the essential oils of Artemisia herbaalba issued from the district of Biskra (Algeria). Phytotherapie 8, 277-281.

Boyraz N., Ozcan M., 2005. Antifungal effect of some spice hydrosols. Fitoterapia 76, 661-665.
BRIDGES J.R., 1987. Effects of terpenoid compounds on growth of symbiotic fungi associated with the southern pine-beetle. Phytopathology 77, 83-85.

Broekaert W.F., Delaure S.L., De Bolle M.F., Cammue B.P., 2006. The role of ethylene in hostpathogen interactions. Annu. Rev. Phytopathol. 44, 393-416.

Chami F., Chami N., Bennis S., Bouchikhi T., Remmal A., 2005. Oregano and clove essential oils induce surface alteration of Saccharomyces cerevisiae. Phytother. Res. 19, 405-408.

Conway W.S., Janisiewicz W.J., Leverentz B., SAFtNer R.A., CAMP M.J., 2007. Control of blue mold of apple by combining controlled atmosphere, an antagonist mixture, and sodium bicarbonate. Postharvest Biol. Tec. 45, 326-332.

Cowger C., Mundt C.C., 2002. Aggressiveness of Mycosphaerella graminicola isolates from susceptible and partially resistant wheat cultivars. Phytopathology 92, 624-630.

Delimi A., Taibi F., Fissah A., Gherib S., Bouhkari M., Chefrrour A., 2013. Bioactivité des huiles essentielles de l'armoise blanche Artemisia herbaalba: effet sur la reproduction et la mortalité des adultes d'un ravageur des denrées stockées Ephestia kuehniella (Lepidoptera). Afr. Sci. 9, 82-90.

DGPCQPA, 2017. "Liste des pesticides homologués." Direction générale de la protection et du contrôle de la qualité des produits agricoles, Tunisia.

Dorman H.J.D., Deans S.G., 2000. Antimicrobial agents from plants: antibacterial activity of plant volatile oils. J. Appl. Microbiol. 88, 308-316.

Doumbouya M., Авo K., Lepengue A., Camara B., Kanko K., Aidara D., ET AL., 2012. Activité comparées in vitro de deux fongicides de synthèse et de deux huiles essentielles, champignons telluriques des cultures maraîchères en côte d'ivoire. J. Appl. Biosci. 50, 3520-3532.

Du Plooy W., Regnier T., Combrinck S., 2009. Essential oil amended coatings as alternatives to synthetic fungicides in citrus post-harvest management. Postharvest Biol. Tec. 53, 117-122.

Ebert D., Bull J.J., 2003. Challenging the trade-off model for the evolution of virulence: is virulence management feasible? Trends Microbiol. 11, 15- 20.

Ebert D., Mangin K.L., 1997. The influence of host demography on the evolution of virulence of a microsporidian gut parasite. Evolution 51, 18281837.

Errampalli D., Crnko N., 2010. Control of blue mold caused by Penicillium expansum on apples 'Empire' with fludioxonil and cyprodinil. Can. J. Plant Pathol. 26(1), 70-75.

Filtenborg O., Frisvad J.C., Thrane U., 1996. Moulds in food spoilage. Int. J. Food Microbiol. 33, 85-102.

Flier W. G., Turkensteen L.J., Mulder A., 1998. Variation in tuber pathogenicity of Phytophthora infestans in the Netherlands. Potato Res. 41, 345-354. 
GIFruITs, 2016. Production fruits 2015. Groupement interprofessionnel des fruits. http://gifruits.com/wpcontent/uploads/prod.pdf.

GrifFin S.G., Leach D.N., Markham J., Johnstone R., 1998. Antimicrobial activity of essential oils from zieria. J. Essent. Oil Res. 10, 165- 174.

Guerrero V., Guigon C., Berlanga D., Ojeda D., 2014. Complete control of Penicillium expansum on apple fruit using a combination of antagonistic yeast Candida oleophila. Chil. J. Agr. Res. 74(4), 427-431.

Guillen F., ZaPATA P.J., Martinez-Romero D., Castillo S., Serrano M., Valero D., 2007. Improvement of the overall quality of table grapes stored under modified atmosphere packaging in combination with natural antimicrobial compounds. J. Food Sci. 72, 185-190.

Hajlaoui H., Trabelsi N., Noumi E., Snoussi M., Fallah H., Ksouri R., ET AL., 2009. Biological activities of the essential oils and methanol extract of tow cultivated mint species (Mentha longifolia and Mentha pulegium) used in the Tunisian folkloric medicine. World J. Microb. Biot. 25, 2227-2238.

Hamdani F. Z., Allem R., Meziane M., Setti B., Ali A.S., Bourai M., 2015. Chemical composition and antifungal activity of essential oils of Algerian citrus. Afr. J. Biotechnol. 14, 1048-1055.

Haouari M., Ferchichi A., 2009. Essential oil composition of Artemisia herba-alba from southern Tunisia. Molecules 14, 1585-1594.

Hmiri S., Amrani N., Rahouti M., 2011. In vitro determination of antifungal activity of eugenol and essential oils of Mentha pulegium L. and Tanacetum annuиm L. against three fungi causing post-harvest rot of apples. Acta Bot. Gallica 158, 609-616.

Hoffmann A.A., Parsons P.A., 1991. Evolutionary Genetics and Environmental Stress. Oxford University Press, Oxford, UK.

Janisiewicz W.J., Saftner R.A., Conway W.S., Yoder K.S., 2008. Control of blue mold decay of apple during commercial controlled atmosphere storage with yeast antagonists and sodium bicarbonate. Postharvest Biol. Tec. 49, 374-378.

Jhalegar M.J., Sharma R.R., Singh D., 2015. In vitro and in vivo activity of essential oils against major post-harvest pathogens of kinnow (Citrus nobilis $\times$ C. deliciosa) mandarin. J. Food Sci. Tech. Mys. 52, 2229-2237.

Jurick W.M., Vico I., Gaskins V.L., Garrett W.M., Whitaker B.D., Janisiewicz W.J., eT AL., 2010. Purification and biochemical characterization of polygalacturonase produced by Penicillium expansum during postharvest decay of 'Anjou' pear. Phytopathology 100, 42-48, doi: 10.1094/ phyto-100-1-0042.

Kanherkar S.H., Shahare N.H., Pachkhede A.U., 2007. Efficacy of some plant extracts against Fusarium oxysporium. J. Plant Dis. Sci. 2, 224-225.
Karaoglanidis G., Markoglou A., Bardas A. G., Doukas G. E., Konstantinou S., Kalampokis I., 2011. Sensitivity of Penicillium expansum field isolates to tebuconazole, iprodione, fludioxonil and cyprodinil and characterization of fitness parameters and patulin production. Int. J. Food Microbiol. 145, 195-204.

Kim J., Lee Y.S., Lee S.G., ShIN S.C., PARK I.K., 2008. Fumigant antifungal activity of plant essential oils and components from west Indian bay (Pimenta racemosa) and thyme (Thymus vulgaris) oils against two phytopathogenic fungi. Flavour Frag. J. 23, 272 277.

Kinay P., Mansour M.F., Gabler F.M., Margosan, D.A., Smilanick J.L., 2007. Characterization of fungicide-resistant isolates of Penicillium digitatum collected in California. Crop Prot. 26, 647-656.

Klaric M.S., Kosalec I., Mastelic J., Pieckova E., PePeljnak S., 2007. Antifungal activity of thyme (Thymus vulgaris L.) essential oil and thymol against moulds from damp dwellings. Lett. Appl. Microbiol. 44, 36-42.

Koella J.C., Agnew P., 1999. A correlated response of a parasite's virulence and life cycle to selection on its host's life history. J. Evolutionary. Biol. 12, 70-79.

Kolai N., Saiah F., Boudia A., 2012. Effet inhibiteur in vitro de l'huile essentielle d'Artimesia herba-alba sur deux souches de Fusarium oxysporum f. sp. radicislycopersici. Algerian J. Arid Environ. 2, 71-76.

Koller W., Wilcox W.F., 2001. Evidence for the predisposition of fungicide- resistant phenotypes of Venturia inaequalis to a preferential selection for resistance to other fungicides. Phytopathology 91, 776-781.

Kong Q.L., Song Y.Z., Zhang L.L., Chen L.Y., Li Q.F., 2004. Natural antifungal compounds from Syzygium aromaticum (L.) Merr. et Perry. Acta Agri. Shanghai 20, 68-72.

Leverentz B., Conway W., Janisiewicz W., Kurtzman C., Abadias M., Camp M., 2005. Biocontrol of foodborne pathogens on fresh-cut apples using naturally occurring bacterial and yeast antagonists. Phytopathology 95, 59.

Li H.X., XIAO C.L., 2008. Characterization of fludioxonilresistant and pyrimethanil-resistant phenotypes of Penicillium expansum from apple. Phytopathology 98, 427-435.

Luw J.P., Korsten L., 2014. Pathogenic Penicillium spp. on apple and pear. Plant Dis. 98, 590-598.

MacHardy W.E., 1996. Apple scab: biology, epidemiology, and management. American Phytopathological Society, St. Paul, Minnesota, USA.

Mahilrajan S., Nandakumar J., KaIlayalingam R., Manoharan N.A., SriviJeindran S., 2014. Screening the antifungal activity of essential oils against decay fungi from palmyrah leaf handicrafts. Biol. Res. 47(1), 35. 
Markoglou A.N., Vattis K., Dikitriadis K., Doukas E.G., Ziogas B.N., 2008. Effect of phenylpyrrole resistance mutations on mycotoxin production by Aspergillus carbonarius and Penicillium expansum. $9^{\text {th }}$ International Congress Of Plant Pathology. ICPP, Torino, Italy.

Mighri H., Akrout A., Neffati M., Tomi F., Casanova J., 2009. The essential oil from Artemisia herbaalba Asso cultivated in arid land (South Tunisia). J. Essent. Oil Res. 21, 453-456.

Montes-Belmont R., Carvajal M., 1998. Control of Aspergillus flavus in maize with plant essential oils and their components. J Food Protect 61, 616-619.

Morales A., Marin S., Ramos A.J., SAnchis V., 2010. Influence of post-harvest technologies applied during cold storage of apples in Penicillium expansum growth and patulin accumulation: A review. Food Control 21, 953-962.

Nguefack J., Nguikwie S.K., Fotio D., Dongmo B., Zollo P.H.A., Leth V., ET AL., 2007. Fungicidal potential of essential oils and fractions from Cymbopogon citratus, Ocimum gratissimum and Thymus vulgaris to control Alternaria padwickii and Bipolaris oryzae, two seed-borne fungi of rice (Oryza sativa L.). J. Essent. Oil Res. 19, 581-587.

Numpaque M.A., Oviedo L.A., Gil J.H., Garcia C.M., Durango D.L., 2011. Thymol and carvacrol: biotransformation and antifungal activity against the plant pathogenic fungi Colletotrichum acutatum and Botryodiplodia theobromae. Trop. Plant Pathol. 36, 3-13.

Ozcan M., Boyraz N., 2000. Antifungal properties of some herb decoctions. Eur. Food Res. Technol. 212, 86-88.

Peakall R., Smouse P.E., 2012. Genalex 6.5: genetic analysis in excel. Population genetic software for teaching and research - an update. Bioinformatics 28, 2537-2539.

Pinto E., Vale-Silva L., Cavaleiro C., Salgueiro L., 2009. Antifungal activity of the clove essential oil from Syzygium aromaticum on candida, Aspergillus and dermatophyte species. J. Med. Microbiol. 58, 1454-1462.

Pirbalouti A.G., Firoznezhad M., Craker L., Akbarzadeh M., 2013. Essential oil compositions, antibacterial and antioxidant activities of various populations of Artemisia chamaemelifolia at two phenological stages. Revista Brasileira De Farmacognosia-Braz J. Pharm. Sci. 23, 861-869.

Plaza P., Torres R., Usall J., Lamarca N., Vinas I., 2004. Evaluation of the potential of commercial postharvest application of essential oils to control citrus decay. J. Hortic. Sci. Biotech. 79, 935-940.

Plotto A., Roberts D.D., Roberts R.G., 2002. Evaluation of plant essential oils as natural postharvest disease control of tomato (Lycopersicon esculentum). In: XXVI International Horticultural Congress: ISS Adv. Post-Harvest Hort. 628, 737-745.
Pontin M., Bottini R., Burba J.L., Piccoli P., 2015. Allium sativum produces terpenes with fungistatic properties in response to infection with Sclerotium cepivorum. Phytochemistry 115, 152-160.

Pottier-Alapetite G., 1981. Flore de la Tunisie, angiospermes - dicotylédones, gamopétales, Imprimerie officielle de la République Tunisienne, ed. Tunisie.

Pradhan S., Flores F.J., Melouk H., Walker N.R., Molineros J.E., Garzon C.D., 2017. Chemical hormesis on plant pathogenic fungi and oomycetes. In: Pesticide Dose: Effects on the Environment and Target and Non-Target Organisms. S.O. Duke, P. Kudsk and K. Solomon (Eds), ACS Symosium Series 1249, 121-133.

Quaglia M., Ederli L., Pasqualini S., Zazzerini A., 2011. Biological control agents and chemical inducers of resistance for postharvest control of Penicillium expansum Link. on apple fruit. Postharvest Biol. Tec. 59, 307-315.

Ranasinghe L., Jayawardena B., Abeywickrama K., 2002. Fungicidal activity of essential oils of Cinnamomum zeylanicum (L.) and Syzygium aromaticum (L.) Merr et L.M. Perry against crown rot and anthracnose pathogens isolated from banana. Lett. Appl. Microbiol. 35, 208-211.

Reznick D., Nunney L., Tessier A., 2000. Big houses, big cars, superfleas and the costs of reproduction. Trends Ecol. Evol. 15, 421-425.

Rosenberger D.A., 2014. Blue mold. In: Compendium of Apple and Pear Diseases and Pests. T.B. Sutton, H.S. Aldwinckle, A.M. Agnello, J.F. Walgenbach (Eds), American Phytopathological Society Press, St Paul, Minnesota, USA, 76-77.

SAGDic O., Ozcan M., 2003. Antibacterial activity of Turkish spice hydrosols. Food Control 14, 141-143.

Saleh M.A., Belal M.H., El-Baroty G., 2006. Fungicidal activity of Artemisia herba-alba Asso (Asteraceae). J. Environ. Sci. Heal B 41, 237-244.

Salido S., Valenzuela L.R., Altarejos J., Nogueras M., Sanchez A., Cano E., 2004. Composition and infraspecific variability of Artemisia herba-alba from southern Spain. Biochem. Syst. Ecol. 32, 265-277.

SERVICE P.M., Rose M.R., 1985. Genetic covariation among life-history components - the effect of novel environments. Evolution 39, 943-945.

Snoussi M., Hajlaoui H., Noumi E., Usai D., Sechi L.A., ZANeTti S., ET AL., 2008. In-vitro anti- Vibrio spp. activity and chemical composition of some Tunisian aromatic plants. World J. Microb. Biot. 24, 3071-3076.

Statsoft Inc., 2001. Statistica (Data Analysis Software System), Ver. 6, www.statsoft.com.

Suryawanshi A.P., LadKat G.M., DhOK P.K., Somwanshi S.D., Pensalwar S.N., 2007. Evaluation of some plant extracts against Sclerotium rofsii on pigeonpea. J. Plant Dis. Sci. 2, 32-33. 
Tessier A.J., Woodruff P., 2002. Trading off the ability to exploit rich versus poor food quality. Ecol. Lett. 5, 685-692.

Ticha J., Hajslova J., Jech M., HonziceK J., Lacina O., Kohoutkova J., ET AL., 2008. Changes of pesticide residues in apples during cold storage. Food Control 19, 247-256.

Tsao R., Zhou T., 2000. Antifungal activity of monoterpenoids against post-harvest pathogens Botrytis cinerea and Monilinia fructicola. J. Essent. Oil Res. 12, 113-121.

Vaughn S.F., Spencer G.F., Shasha B.S., 1993. Volatile compounds from raspberry and strawberry fruit inhibit post-harvest decay fungi. J. Food Sci. 58(4), 793-796.

Van Noordwijk A.J., Dejong G., 1986. Acquisition and allocation of resources - their influence on variation in life-history tactics. Am. Nat. 128, 137-142.

Vernin G., Merad O., Vernin G.M.F., Zamkotsian R.M., ParkanyI C., 1995. GC-MS analysis of Artemisia herba-alba Asso essential oils from Algeria. In: Food Flavors: Generation, Analysis and Process Influence. G. Charalambous (Ed.), Elsevier Science, 147-205.

Vico I., Duduk N., Vasic M., Nikolic M., 2014. Identification of Penicillium expansum causing postharvest blue mold decay of apple fruit. Pesticidi i Fitomedicina 29, 257-266.
Wallace L.R., Hirkala D.L., Nelson L.M., 2017. Postharvest biological control of blue mold of apple by Pseudomonas fluorescens during commercial storage and potential modes of action. Postharvest Biol. Tec. 133, 1-4.

Wojcik-Stopczynska B., Jakowienko P., WysockA G., 2012. The estimation of antifungal activity of essential oil and hydrosol obtained from wrinkledleaf mint (Mentha crispa L.). Herba Polonica 58, 5-15.

Xiao L., Boal R., 2009. Residual activity of fludioxonil and pyrimethanil against Penicillium expansum on apple fruit. Plant Dis. 93, 1003-1008, doi: 10.1094/ pdis-93-10-1003.

Zera A.J., Harshman L.G., 2001. The physiology of life history trade-offs in animals. Annu. Rev. Ecol. Syst. 32, 95-126.

Ziogas B.N., Markoglou A.N., Spyropoulou V., 2005. Effect of phenylpyrrole - resistance mutations on ecological fitness of Botrytis cinerea and their genetical basis in ustilago maydis. Eur. J. Plant Pathol. 113, 83-100.

Zuzarte M., Goncalves M.J., Cavaleiro C., Dinis A.M., CAnhoto J.M., Salgueiro L.R., 2009. Chemical composition and antifungal activity of the essential oils of Lavandula pedunculata (Miller) Cav. Chem. Biodivers. 6, 1283-1292.

Received November 25, 2018; accepted May 9, 2019 